Regional Aesthetics 



\section{Regional Aesthetics}

\section{Mapping UK Media Cultures}

Edited by

Ieuan Franklin

Bournemouth University, UK

Hugh Chignell

Bournemouth University, UK

and

Kristin Skoog

Bournemouth University, UK 


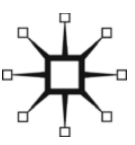

Introduction (๑) leuan Franklin 2015

Selection and editorial matter (c) leuan Franklin, Hugh Chignell and Kristin Skoog 2015

Foreword (C) Mats Jönsson 2015

Individual chapters (C) Respective authors 2015

Softcover reprint of the hardcover 1st edition 2015 978-1-137-53282-4

All rights reserved. No reproduction, copy or transmission of this publication may be made without written permission.

No portion of this publication may be reproduced, copied or transmitted save with written permission or in accordance with the provisions of the Copyright, Designs and Patents Act 1988, or under the terms of any licence permitting limited copying issued by the Copyright Licensing Agency, Saffron House, 6-10 Kirby Street, London EC1N 8TS.

Any person who does any unauthorized act in relation to this publication may be liable to criminal prosecution and civil claims for damages.

The authors have asserted their rights to be identified as the authors of this work in accordance with the Copyright, Designs and Patents Act 1988.

First published 2015 by

PALGRAVE MACMILLAN

Palgrave Macmillan in the UK is an imprint of Macmillan Publishers Limited, registered in England, company number 785998, of Houndmills, Basingstoke, Hampshire RG216XS.

Palgrave Macmillan in the US is a division of St Martin's Press LLC, 175 Fifth Avenue, New York, NY 10010.

Palgrave Macmillan is the global academic imprint of the above companies and has companies and representatives throughout the world.

Palgrave ${ }^{\circledR}$ and Macmillan ${ }^{\circledR}$ are registered trademarks in the United States, the United Kingdom, Europe and other countries.

ISBN 978-1-349-57093-5 ISBN 978-1-137-53283-1 (eBook)

DOI $10.1057 / 9781137532831$

This book is printed on paper suitable for recycling and made from fully managed and sustained forest sources. Logging, pulping and manufacturing processes are expected to conform to the environmental regulations of the country of origin.

A catalogue record for this book is available from the British Library.

Library of Congress Cataloging-in-Publication Data

Regional aesthetics : mapping UK media cultures / edited by leuan Franklin, Bournemouth University, UK ; Hugh Chignell, Bournemouth University, UK ; Kristin Skoog, Bournemouth University, UK. pages $\mathrm{cm}$

1. Local mass media - Great Britain. 2. Mass media and culture - Great Britain. I. Franklin, leuan, 1980- editor. II. Chignell, Hugh, editor. III. Skoog, Kristin, 1979- editor. 
Ieuan Franklin would like to dedicate this book to the memory of Derek Allsop (1968-2014) - Northern powerhouse 



\section{Contents}

List of Figures ix

Foreword

Mats Jönsson

Acknowledgements - xi

Notes on Contributors xii

Introduction $\quad 1$

Ieuan Franklin

\section{Part I Living on Location}

1 Living on Location: Amateur Creativity and Negotiating a Sense of Place in Yorkshire

Heather Norris Nicholson

2 Arcadia in Absentia: Cinema, the Great Depression and the Problem of Industrial Wales

Daryl Perrins

3 A Poetics of the North: Visual and Literary Geographies David Forrest and Sue Vice

\section{Part II Urban Subcultures and Structures of Feeling}

4 The Sons and Heirs of Something Particular: The Smiths' Manchester Aesthetic, 1982-1987

Peter Atkinson

5 Away and Raffle Yourself! Still Game, Craiglang, Glasgow and Identity

Mary Irwin

6 Topological London

Kris Erickson 


\section{Part III Broadcasting and Belonging}

7 A Region in Microcosm: Brandon Acton-Bond's Post-War BBC Radio Features

Ieuan Franklin

8 Gi' It Some 'Ommer: ITV Regional Programming and the Performance of the Black Country

Julie E. Robinson

9 A Post-War History of Radio for the Asian Community in Leicester

Gloria Khamkar

10 The Teliesyn Co-operative: National Broadcasting, Production Organisation and TV Aesthetics

Dafydd Sills-Jones

\section{Part IV Borders, Devolution and Contested Histories}

11 Sam Hanna Bell and the Ideology of Place

Hugh Chignell

12 Resisting Redefinition: The Portrayal of Northern Irish

Identity in Ulster Television's Schools Output, 1970-1977 Ken Griffin

13 'Nothing Similar in England': The Scottish Film Council, the Scottish Education Department and the Utility of 'Educational Film' to Scotland

Mandy Powell

14 Impossible Unity? Representing Internal Diversity in

Post-Devolution Wales

Simon Gwyn Roberts 


\section{List of Figures}

1 'My Irish Molly! O!' No. 2, from the 1905-1906 season series of illustrated 'life model' postcards based on popular pantomime songs, produced by Bamforth and Co., Holmfirth

2 'How the "life models" are taken'

3 James Bamforth demonstrating 'I only want an hour's notice to illustrate any song on the market' to magazine representative (with notebook), cited in The Caxton Magazine/The British Stationer, January 1906, p. 3

4 The Counties of Wales, 1543-1973

5 'Here once was Wales': despoliation in the opening shots of How Green Was My Valley (John Ford, 1941)

6 'Dam and blast it, man, aren't we all black down that pit?' The pithead confrontation in The Proud Valley (Pen Tennyson, 1940)

7 Jack and Victor, Still Game (BBC Scotland, 2002-2007)

8 Detail of 1933 printed edition of Beck's London Underground map

9 A virtual projection of London used to prepare security forces in advance of the 2012 Olympics

10 Typology of mobile software applications tagged with 'London'

11 John McCavert introduces 'Belfast', a 1973 episode of Let's Look at Ulster

12 The This Island About Us logo as seen in the first episode of the series 


\section{Foreword}

In 2006, the European Network for Cinema and Media Studies (NECS) was inaugurated at the Historical Museum in Berlin. Three years later, I organised the third NECS conference, 'Locating Media', at Lund University, Sweden. The results had profound effects on the scholarly work in Lund, not least on the anthology Regional Aesthetics: Locating Swedish Media (2010), which gathered some of the NECS presentations about Sweden. Last year, I learnt that media historians at Bournemouth University had initiated a volume with similar perspectives on the British media. And after reading this exciting volume, I am now convinced that national perspectives on relations between space, place and media will continue to constitute a significant research area for many years to come. Our global and glocal ways of living have led to an increased general interest in the regional, local and individual.

In addition the inward-looking, almost centripetal, tendencies of domestic national media across the world have exposed the invariable need for historical and comparative perspectives on these matters across borders geographically, mentally and medially. As expected, however, there are of course risks connected to such research. Even though we never intended to publish a Swedish volume with nationalistic tendencies back in 2010, we soon realised that to some foreign readers our concentration on domestic vernacular media made the book seem stripped of critical perspectives on nationalism. Now, I am not in any way suggesting that the same is true with regard to the new British anthology - on the contrary. Rather, the point is that we should never underestimate the nationalistic aspects of regional and local media or, for that matter, of regional and local media studies. For these and several other reasons, Regional Aesthetics: Mapping UK Media Cultures constitutes a timely collection of sharp analyses that skilfully reveal the complex and entangled nature of regional and local media cultures in the UK. It offers new, thought-provoking insights into a century of British media culture with obvious domestic relevance, but which certainly also will prove useful for future research in many different areas, disciplines and nations. 


\section{Acknowledgements}

First and foremost, we would like to thank all of the authors of this collection, some of whom we met for the first time when we invited them to deliver 'work in progress' papers at an 'authors' meeting' at Bournemouth University on 6 September 2013. This meeting was an opportunity not only to give feedback on each other's work, but also to discuss the project as a whole, and so our vision of the book was very much influenced by the thoughts of our authors. We would like to acknowledge the support of Mats Jönsson and Patrik Lundell of Lund University, who both encouraged us to write this book and provided the initial inspiration for it, in the form of the Swedish Regional Aesthetics collection (edited by Erik Hedling, Olof Hedling and Mats Jönsson). To this end we would also like to thank all the authors who contributed to that collection.

Many of the chapters in our collection are notable for their use of archival research, and we would like to thank various archives and their staff, and acknowledge the use of their materials, particularly: BBC Written Archives, BBC Northern Ireland Community Archive, the Media Archive for Central England (MACE) and Ulster Television (UTV). 


\section{Notes on Contributors}

Peter Atkinson is Course Leader in Film and Media at the University of Central Lancashire. He has produced academic work on the role of broadcasting and the Beatles in the emergent myth of Liverpool 19581964, on Abbey Road Studios, tourists and Beatles' heritage, and on verse-film juxtaposition in TV documentary.

Hugh Chignell is Professor of Media History and Director of the Centre for Media History at Bournemouth University. He is a chair of the UK Radio Archives Advisory Committee. His published research is mainly on radio history, including news, current affairs and radio drama.

Kris Erickson is Lord Kelvin Adam Smith Research Fellow in Social Sciences at the University of Glasgow. He holds a PhD in Human Geography from the University of Washington in Seattle, where he studied online hacker communities. His current research investigates the intellectual property status of amateur cultural production, in particular recombinatory expressions such as parody, remix and fan work.

David Forrest is Lecturer in Film Studies at the School of English, University of Sheffield. His research focuses mainly on social realism in film and television, and his upcoming book (written with Sue Vice) is a study of South Yorkshire writer Barry Hines.

Ieuan Franklin is Lecturer in Film and Media at Wiltshire College, Salisbury and Bournemouth University. His PhD explored the relationship between oral history and radio broadcasting in the UK. Between 2010 and 2014 he worked as a research assistant on the AHRC-funded 'Channel 4 and British Film Culture' project at the University of Portsmouth.

Ken Griffin is a freelance postdoctoral media researcher who specialises in regional television, media historiography and archival silences. He is currently working with Ulster University on a project focused on preserving interstitial material, which is partly funded by the Broadcasting Authority of Ireland.

Mary Irwin is Lecturer in Media at Northumbria University. She specialises in television studies with particular interests in television history, television comedy and drama, and genre and gender. She has 
published widely in the areas of historical and contemporary television and is currently writing a monograph: Love Wars: Television Romantic Comedy.

Gloria Khamkar is a doctoral researcher at Bournemouth University, examining the 'Evolution of Asian Radio Broadcasting in England'. She works as a part-time radio lecturer at the University of West London, and presents a radio show at Southampton's Asian community radio station, Unity101.1FM.

Heather Norris Nicholson is a visiting research fellow at the Centre for Visual and Oral History Research at the University of Huddersfield. Her publications on identity, representation and amateur visual culture include Amateur Film: Meaning and Practice, 1927-77 (2012), and she is currently co-writing a book on women amateur filmmakers.

Daryl Perrins is Senior Lecturer in Film Studies at the Cardiff School of Creative and Cultural Industries, University of South Wales. He is also a PhD candidate at Royal Holloway College, University of London. His post-graduate research centres on the representation of the Welsh working class in film and television.

Mandy Powell is Research Fellow in Media, Communications and Performing Arts at Queen Margaret University in Edinburgh. Previously she was a researcher at the University of London working on a three-year ESRC-funded project: Developing Media Literacy; she has published on media education and media literacy. Her current research interest is in practice communities with a specific focus on the production of educational film in the UK.

Simon Gwyn Roberts is Senior Lecturer in Journalism and Media at the University of Chester, and Deputy Head of the Media Department. His research interests include the relationship between the news media and political devolution, and the role of online media in the communication strategies of minorities.

Julie E. Robinson completed her PhD in Regional Television History at the University of Leicester in 2014. Her research project, funded by an AHRC Collaborative Doctoral Award, considered the history of ITV regional programming in the Midlands based on the ATV/Central Independent Television collection held at the Media Archive for Central England. She is currently working in academic services development for the University of Warwick Library. 
Dafydd Sills-Jones is Lecturer in Media Production Cultures at Aberystwyth University. His research interests include media production studies, including television documentary in the UK and Scandinavian cinematic documentary. Before becoming an academic he worked in the media-production industries for ten years.

Kristin Skoog is Lecturer in Media Theory at Bournemouth University, where she is also Assistant Director of the Centre for Media History. Her research focus is centred around twentieth-century radio and media history and, in particular, women's radio and reconstruction in post-war Britain and Europe.

Sue Vice is Professor of English Literature at the University of Sheffield. She has written on such topics as the work of Jack Rosenthal and Claude Lanzmann, and her most recent book is Textual Deceptions (2014), a study of literary hoaxes and false memoirs. 